\title{
The Effect of Board Structure on Banks Financial Performance by Moderating Firm Size
}

\author{
Fazel Mohammadi Nodeh
}

Melati Ahmad Anuar*

\author{
Suresh Ramakrishnan
}

\author{
Ali Akbar Raftnia \\ ${ }^{*}$ Faculty of management, University Technology Malaysia, 81310 Skudai, Johor bahru, Malaysia \\ Mnfazel2@live.utm.my; *m-melati@utm.my
}

\section{Doi:10.5901/mjss.2016.v7n1p258}

\begin{abstract}
The objective of this study is to provide a comprehensive overview of possible influences that the key players of determinants of board structure - board size and board independence, might have on banks financial performance path to success. Dissimilar with recent researches which were focused to test corporate governance influences on firm performance, this study investigates the role of bank size (log of asset) as moderator on relationship between board size and board independence with banks financial performance. The data of 37 Malaysian banks (21conventional, 16 Islamic) is analyzed by regression models using StataSE 12 software. The results show that the relationship between determinants of board structure (board size, and board independence) and financial performance moderated by firm size.
\end{abstract}

Keywords: Board Structure, Banks Financial Performance, Firm Size

\section{Introduction}

The last few decades have witnessed several economic downturns and a large number of corporate scandals across the world. Corporate governance is an important issue due to these financial scandals, and has been taken in to consideration by researchers as well as investors. Investigations the causes and conditions of the scandals have identified, lack of management oversight, and weakness of corporate governance structure. Furthermore, entrusting unlimited authority to executives also provided desirable ground for abuse. All those conditions led to scandals in big companies around the world, including well-known companies like; World Come Inc, Enron, and Adelphia (Munzig, 2003). To avoid such situations, proper governance of stakeholders through regular monitoring and auditing of the executive management is required, which is a process known as corporate governance. The current study investigates the relationship between board structure (size of board, board independence) and financial performance of banks. Regardless of investigating the linkage of these variables, the role of firm size as moderator, recognized on relationship between determinants of board structure and banks financial performance.

Generally, this study fills the gap in the literature series by capturing the impact of size of firm in financial performance of banks as moderator. In relation to this point, number of studies such as; (Ferrero-Ferrero, FernándezIzquierdo, \& Muñoz-Torres, 2012; Haniffa \& Hudaib, 2006; Hu \& Izumida, 2008; Kryvko, 2012; Munisi \& Randøy, 2013), investigated the effect of corporate governance determinants such as size of board, board independence, on firm performance. They did not address the effect of size of firm on the relationship between those determinants and performance. This study provides useful guidelines for the corporate sectors, financial institutions, shareholders, depositors, and investors. The guidelines could assist firms to react effectively and efficiently during different economic conditions. Moreover, this study provides a good recipe for managers to consider an appropriate set of corporate governance model related to specific systems of banks in their decision making. It highly important to explore the role of variables that may influence the financial performance of banks.

\section{Literature Review}

Since the study of Williamson (1979) corporate governance becomes an important issue in both financial and nonfinancial firms. Based on his study, the subject of corporate governance mechanisms is of great practical importance and 
it is mentioned as a concept for the first time. This subject either in advanced financial markets have a great deal of differences on how good or bad the existing governance systems are. For instance, Romano (1993) and Easterbrook (1996) created an incredibly beneficial analysis for the U.S corporate governance system, whereas Jensen (1989) and Jensen (1993) believed that the current corporate systems should move toward a more leveraged organization. Understanding corporate governance not only clarifies the debate associated with possible change in rich economies but also induce significant institutional changes where they must be implemented.

Majority of the discussion in the area of corporate governance has focused on understanding the relationship between corporate governance and firm performance (Cadbury et al., 1992; Dunlop, 1998; Shleifer \& Vishny, 1997). Prior research on the relationship between corporate governance and company performance mentioned that a stronger corporate governance is related to a stronger company performance (Ammann, Oesch, \& Schmid, 2011; Bebchuk, Cohen, \& Ferrell, 2009; Core, Guay, \& Rusticus, 2006; Cremers \& Nair, 2005; Gompers, Ishii, \& Metrick, 2003; Yermack, 1996). In addition, the role of corporate governance in the banking industry was examined in many studies which showed that effective corporate governance had positive effect on bank performance (Laeven \& Levine, 2009; Macey \& O'hara, 2003; Mishra \& Nielsen, 2000; Sierra, Talmor, \& Wallace, 2006). However number of study mentioned that banks corporate governance is different from nonfinancial firms it might because banks has many more stakeholders and business of banks are opaque and complex (Adams \& Mehran, 2003; Andres \& Vallelado, 2008; Bolton, Mehran, \& Shapiro, 2011). Dedu and Chitan (2013), investigate the influence of internal corporate governance on bank performance and find negative relationship between them. Moreover, many scholars recommended that better financial performance relates to good governance, and powerful procedures may constraint managerial opportunisms (Bebchuk et al., 2009; Cremers \& Nair, 2005; Gompers et al., 2003).

Regarding to the factors, that may influence firm performance; the firm size is an important factor that has a considerable effect on performance. Researchers indicated that firm size can potentially affect performance level (Serrasqueiro \& Nunes, 2008; Singh \& Whittington, 1975; Yang \& Chen, 2009). A number of studies mentioned that firm size is a significant determinant may be related to the firms failure or success (Altman \& McGough, 1974; Ohlson, 1980). In contrast, according to Akkaya and Uzar (2011), large firms are more diversified, therefore they face less possibility of default than smaller firms. Other empirical studies showed positive relationship between small-sized firms and performance, while the relationship was inversed for larger firms (Diaz \& Sanchez, 2008; Serrasqueiro \& Nunes, 2008).

In addition, with regard to effect of size of a firm on performance, many scholars have investigated the role of firm size as a control variable on firm performance (Diaz \& Sanchez, 2008; Yang \& Chen, 2009). However, Serrasqueiro and Nunes (2008) used the same variable as independent variable and found positive relationship between size and firms performance. There is no evidence to show the effect of size as a moderate variable on the relationship between corporate governance and performance. Therefore, the role of firm size investigated as a moderator variable.

\section{Data Collection and Variables Definitions}

This study utilizes panel data techniques due to the nature of data that involves the combination of cross-sections and time series, and is based on the number of banks across a 10 year period, data collected from annual reports of banks. By using panel data analysis, the degree of freedom can be increased and its lead to efficient estimates (Antoniou, Guney, \& Paudyal, 2008). Table 1, shows the variables and their description in this study

Table 1: Variables

\begin{tabular}{|l|l|l|}
\hline Variables & Description & Measurement \\
\hline ROA & Return on Asset & Net income /total asset \\
\hline ROE & Return on Equity & Net income/total equity \\
\hline BIND & Board Independence & Number of independent non-executive directors in a board \\
\hline BSIZE & Board size & Number of directors in a board \\
\hline FSIZE & Firm Size & Natural log of total asset \\
\hline
\end{tabular}

\section{Methods and Hypotheses Testing}

There are two objectives in this study which are; (a) to investigate whether there is significant relationship between board independence and board size with banks financial performance. (b) To investigate the role of firm size as moderate variables on relationship between board independence and board size with financial performance. Therefor the 
hypotheses of this study are as follows:

$\mathrm{H}_{1}$. There is a significant and positive relationship between board size and financial performance of bank.

$\mathrm{H}_{2}$. There is a significant and positive relationship between board independence and financial performance of bank.

The following econometric models used to tests these hypotheses:

$p_{i t}=\alpha+\beta_{1}$ Bind $_{i t}+\beta_{2}$ Bsize $_{i t}+\varepsilon_{i t}$

$p_{i t}=\alpha+\beta_{1}$ Bind $_{i t}+\beta_{2}$ Bsize $_{i t}+\mu_{i}+\varepsilon_{i t}$

(2) Where: $p_{i t}=$ Financial performance (ROE, ROA); Bind, board independence; Bsize, board size; $\mu_{i}$ firm fixed effect cross sectional differences in firm characteristics. Table indicate the result of fixed effect regression of corporate governance on financial performance.

$\mathrm{H}_{3}$. Firm size moderated the relationship between board structure and banks financial performance.

$p_{i t}=\alpha+\beta_{1}$ Bind $_{i t}+\beta_{2}$ Bsize $_{i t}+\beta_{3}$ Fsize $_{i t}+\beta_{4}$ Bind $_{i t} *$ Fsize $_{i t}$

$+\beta_{5}$ Bsize $_{i t} *$ Fsize $_{i t}+\varepsilon_{i t}$

(3) Where: $p_{i t}=$ Financial performance (ROE, ROA), Bind: board independence, Bsize: board size, Bind*Fsize and Bsize*Fsize: interaction terms.

In testing this model, Hierarchical moderated multiple regression models is used to minor extension of an ordinary multiple regression. This method allowed the relationship between independent variables and dependent variables influence by third variable (i.e. moderator). According to (Bisbe \& Otley, 2004), the Hierarchical moderated multiple regression models is an appropriate method for identifying the effect of moderating variables. The current study used three model or steps in order to testing hierarchical moderated multiple regression. Model 1, banks financial performance is regressed on the independent variables. Model2, banks financial performance is regressed on the independent variables and bank size as moderator variable. Model3. Finally in model 3 , the banks financial performance is regressed on independent variables, moderating variables and interaction terms (independent variables $\mathrm{x}$ moderating variable).

\section{Empirical Results}

This study employs the econometric analysis using panel data that combines the features of time-series and crosssectional data. In line with the objectives of this study, this study used two main estimations; Ordinary Least Squares (OLS) and Fixed Effect Method. Table 2 shows the result of Variable inflation factors and Heteroscedastisity test.

Table 2: VIF and Hettest results

\begin{tabular}{|c|c|c|c|c|}
\hline \multirow{2}{*}{ Variable } & \multicolumn{2}{|c|}{ ROE, ROA } & \multicolumn{2}{|c|}{ Hottest, Breusch-Pagan, heteroskedasticity } \\
\hline & VIF & Tolerance & ROE & ROA \\
\hline $\begin{array}{c}\text { Bind } \\
\text { Bsize } \\
\text { Mean VIF }\end{array}$ & $\begin{array}{l}1.80 \\
1.80 \\
1.80\end{array}$ & $\begin{array}{l}0.556 \\
0.556\end{array}$ & $\begin{array}{c}\operatorname{chi} 2(1)=0.02 \\
\text { Prob }>\text { chi2 }=0.893\end{array}$ & $\begin{array}{c}\text { chi2(1) }=2.54 \\
\text { Prob }>\text { chi2 }=0.1107\end{array}$ \\
\hline
\end{tabular}

The result of variable inflation factors (VIF) and tolerance values were less than 10 and more than 0.10 respectively, table 2 shows that there is no multicolinearity problem among independent variables. To test the equal variance of dependent variable (homoscedasticity), Breusch-Pagan or Cook-Weisberg test was applied (Breusch and Pagan1979), table 2. This table presents that there is no Heteroscedastisity problem in variance of independent variable. Therefore the model regressed by using ordinary least squares regression (OLS), and fixed effect model as additional test, Table 3.

Table 3: OLS and Fixed effect

\begin{tabular}{lcccc}
\hline \multirow{2}{*}{ Variables } & \multicolumn{2}{c}{ OLS } & \multicolumn{2}{c}{ Fixed Effect Method } \\
\cline { 2 - 5 } BIND & ROE & ROA & ROE & ROA \\
BSIZE & $0.966^{* *}$ & $0.4369^{*}$ & $0.540^{* *}$ & $0.1269^{*}$ \\
-CON & $0.1912^{*}$ & $0.1113^{*}$ & $0.4490^{*}$ & $0.1471^{*}$ \\
R-squared & 7.9122 & 3.9510 & 8.3207 & 4.7298 \\
Adj R-squared & 0.0592 & 0.0430 & 0.0546 & 0.05706 \\
F-Value(Sig.F) & 0.0539 & 0.0351 & & \\
NO of Obs & $11.10(0.000)$ & $8.10(0007)$ & $11.74(0.0000)$ & $15.15(0.0000)$ \\
& 356 & 356 & 356 & 356 \\
\hline & & & & \\
& & 0 & &
\end{tabular}


Table 3, presents the results of OLS and fixed effects regression on the relationship between board independence and board size with banks financial performance. As shown in Table 3, board independence and board size positively and significantly influence the banks financial performance in both OLS and Fixed effect methods, which indicated that the there is significant relationship between these variables and financial performance. According to the agency theory which predicts that where a board of director is more independent of management; firm performance would be positively influenced. The result of this study is consistent with findings of number of researches such as; (Belkhir, 2009; Johl, Kaur, \& Cooper, 2013; Liu, Miletkov, Wei, \& Yang, 2015; Nodeh, Anuar, Ramakrishnan, Rafatnia, \& Nodeh, 2015; Sanda, Garba, \& Mikailu, 2011; Shukeri, Shin, \& Shaari, 2012). Table 4, shows the results of moderator variable on relationship between independent variables (BIND, BSIZE) and financial performance (ROE, ROA).

Table 4: The moderating effect of Fsize among Bind, Bsize and financial performance

\begin{tabular}{|c|c|c|c|c|c|c|}
\hline Variables & Moc & & & el 2 & Mod & \\
\hline Financial performance & ROE & ROA & ROE & ROA & ROE & ROA \\
\hline Bind & $0.966^{\star \star \star}$ & $0.4369^{*}$ & $0.988^{\star \star \star}$ & $0.3485^{* *}$ & $5.498 * *$ & $0.5511 *$ \\
\hline Bsize & $0.1912^{*}$ & $0.1113^{*}$ & $0.3923^{\star \star}$ & $0.2127^{*}$ & $20.154^{* *}$ & $2.084^{*}$ \\
\hline FSIZE & & & $6.782^{\star \star \star}$ & $0.4673^{\star \star \star}$ & $27.062^{\star \star \star}$ & $1.528^{\star *}$ \\
\hline Bind*FSIZE & & & & & $1.60193^{* \star}$ & $0.074^{\star}$ \\
\hline Bsize*FSIZE & & & & & $2.7692^{* \star}$ & $0.2805^{*}$ \\
\hline Prob $>F$ & 0.0000 & 0.0007 & 0.0000 & 0.0018 & 0.0000 & 0.0009 \\
\hline $\mathbf{R}^{2}$ & 0.0592 & 0.0430 & 0.1494 & 0.0417 & 0.1748 & 0.0575 \\
\hline Adjust $\mathrm{R}^{2}$ & 0.0539 & 0.0351 & 0.1566 & 0.0335 & 0.1631 & 0.0440 \\
\hline $\begin{array}{l}\text { No of observation } \\
{ }^{*} \text { significant at the } 0.1 \text { le }\end{array}$ & $\begin{array}{r}35 \\
\text { signific }\end{array}$ & $\begin{array}{l}6 \\
\text { ance at }\end{array}$ & e 0.05 lev & 6 & $\begin{array}{r}35 \\
\text { nt at the } C\end{array}$ & 01 level \\
\hline
\end{tabular}

Finding for regression in table 4 answer the hypotheses of $\mathrm{H} 1$ and $\mathrm{H} 2$ as indicated in table 2 also. Further, model 2 indicate a significant result of SIZE, showing the significant impact of bank size on financial performance. In addition, the regression result on the interaction effects of bank size on the relationship between BIND and BSIZ with financial performance demonstrated that firm size has positive effect on financial performance (model3). According to the model 3 results, firm size (size) play as a moderator, which lead to acceptance of hypothesis H3. The finding suggests that firm size have impact on banks financial performance which is consistent with the results of (Ntim, Lindop, \& Thomas, 2013; Serrasqueiro \& Nunes, 2008).

\section{Conclusion}

This study empirically investigates the effects of board structure determinants (board independence, board size) on banks financial performance. Covers the entire populations of commercial banks in Malaysia (37 banks, 21 conventional and 16 Islamic) from 2005 - 2014, however this study examine the role of firm size as moderator on relationship between board independence and board size with firm financial performance. Using panel data analysis, OLS and fixed effect models indicated that board independence and board size positively has impact on firm financial performance. In addition, firm size positively moderated the relationship between board structure determinants and bank financial performance.

\section{References}

Adams, R., \& Mehran, H. (2003). Is corporate governance different for bank holding companies? Available at SSRN 387561.

Akkaya, G. C., \& Uzar, C. (2011). Data Mining in Financial Application. Journal of Modern Accounting and Auditing, 7(12), $1362-1367$.

Altman, E. I., \& McGough, T. (1974). Evaluation of a company as a going concern. Journal of Accountancy, 138(6), 50-57.

Ammann, M., Oesch, D., \& Schmid, M. M. (2011). Corporate governance and firm value: International evidence. Journal of Empirical 
Finance, 18(1), 36-55.

Andres, P. d., \& Vallelado, E. (2008). Corporate governance in banking: The role of the board of directors. Journal of Banking \& Finance, 32(12), 2570-2580.

Antoniou, A., Guney, Y., \& Paudyal, K. (2008). The determinants of capital structure: capital market-oriented versus bank-oriented institutions. Journal of financial and quantitative analysis, 43(1), 59.

Bebchuk, L., Cohen, A., \& Ferrell, A. (2009). What matters in corporate governance? Review of Financial Studies, 22(2), 783-827.

Belkhir, M. (2009). Board structure, ownership structure and firm performance: evidence from banking. Applied financial economics, 19(19), 1581-1593.

Bisbe, J., \& Otley, D. (2004). The effects of the interactive use of management control systems on product innovation. Accounting, organizations and society, 29(8), 709-737.

Bolton, P., Mehran, H., \& Shapiro, J. (2011). Executive compensation and risk taking. FRB of New York Staff Report(456).

Cadbury, A., Butler, J., Lipworth, S., Macdonald, N., Smith, A. H., Brown, S., . . Collum, H. (1992). Committee On The Financial Aspects Of Corporate Governance. Gee, London.

Core, J. E., Guay, W. R., \& Rusticus, T. O. (2006). Does weak governance cause weak stock returns? An examination of firm operating performance and investors' expectations. the Journal of Finance, 61(2), 655-687.

Cremers, K., \& Nair, V. B. (2005). Governance mechanisms and equity prices. the Journal of Finance, 60(6), 2859-2894.

Dedu, V., \& Chitan, G. (2013). The Influence of Internal Corporate Governance on Bank Performance - An Empirical Analysis for Romania. Procedia - Social and Behavioral Sciences, 99(0), 1114-1123. doi: http://dx.doi.org/10.1016/j.sbspro.2013.10.585

Diaz, M. A., \& Sanchez, R. (2008). Firm size and productivity in Spain: a stochastic frontier analysis. Small Business Economics, 30(3), 315-323.

Dunlop, A. (1998). Corporate governance and control: Kogan Page Publishers.

Easterbrook, F. H. (1996). The economic structure of corporate law: Harvard University Press.

Ferrero-Ferrero, I., Fernández-Izquierdo, M. Á., \& Muñoz-Torres, M. J. (2012). The impact of the board of directors characteristics on corporate performance and risk-taking before and during the global financial crisis. Review of Managerial Science, 6(3), 207-226.

Gompers, P., Ishii, J., \& Metrick, A. (2003). Corporate governance and equity prices. The Quarterly Journal of Economics, 118(1), 107156.

Haniffa, R., \& Hudaib, M. (2006). Corporate governance structure and performance of Malaysian listed companies. Journal of Business Finance \& Accounting, 33(7-8), 1034-1062.

Hu, Y., \& Izumida, S. (2008). Ownership concentration and corporate performance: A causal analysis with Japanese panel data. Corporate Governance: An International Review, 16(4), 342-358.

Jensen, M. C. (1989). Eclipse of the public corporation. Harvard Business Review, 67(5), 61-74.

Jensen, M. C. (1993). The modern industrial revolution, exit, and the failure of internal control systems. the Journal of Finance, 48(3), 831-880.

Johl, S. K., Kaur, S., \& Cooper, B. J. (2013). Board characteristics and firm performance: evidence from Malaysian public listed firms. Journal of Economics, Business and Management, 3(2).

Kryvko, A. a. P. R. (2012). Corporate governance and performance of European commercial banks. Paper presented at the international conference "Improving financial institutions: the proper balance between regulation and governance".

Laeven, L., \& Levine, R. (2009). Bank governance, regulation and risk taking. Journal of Financial Economics, 93(2), 259-275.

Liu, Y., Miletkov, M. K., Wei, Z., \& Yang, T. (2015). Board independence and firm performance in China. Journal of Corporate Finance, 30, 223-244. doi: http://dx.doi.org/10.1016/j.jcorpfin.2014.12.004

Macey, J., \& O'hara, M. (2003). The corporate governance of banks. Economic Policy Review, 9(1).

Mishra, C. S., \& Nielsen, J. F. (2000). Board independence and compensation policies in large bank holding companies. Financial Management, 51-69.

Munisi, G., \& Randøy, T. (2013). Corporate governance and company performance across Sub-Saharan African countries. Journal of Economics and Business, 70(0), 92-110. doi: http://dx.doi.org/10.1016/j.jeconbus.2013.08.003

Munzig, P. G. (2003). Enron and the economics of corporate governance. Munzig, Dep. Of Economics Stanford University CA, 9430596072.

Nodeh, F. M., Anuar, M. A., Ramakrishnan, S., Rafatnia, A. A., \& Nodeh, A. M. (2015). Mediating Risk Taking on Relationship between Board Structure Determinants and Banks Financial Performance. Asian Social Science, 11(23), p96.

Ntim, C. G., Lindop, S., \& Thomas, D. A. (2013). Corporate governance and risk reporting in South Africa: A study of corporate risk disclosures in the pre- and post-2007/2008 global financial crisis periods. International Review of Financial Analysis, 30(0), 363383. doi: http://dx.doi.org/10.1016/j.irfa.2013.07.001

Ohlson, J. A. (1980). Financial ratios and the probabilistic prediction of bankruptcy. Journal of accounting research, 18(1), 109-131.

Romano, R. (1993). The genius of American corporate law: American Enterprise Institute.

Sanda, A., Garba, T., \& Mikailu, A. S. (2011). Board independence and firm financial performance: evidence from Nigeria: African Economic Research Consortium.

Serrasqueiro, Z. S., \& Nunes, P. M. (2008). Performance and size: empirical evidence from Portuguese SMEs. Small Business Economics, 31(2), 195-217.

Shleifer, A., \& Vishny, R. W. (1997). A survey of corporate governance. the Journal of Finance, 52(2), 737-783.

Shukeri, S. N., Shin, O. W., \& Shaari, M. S. (2012). Does board of director's characteristics affect firm performance? Evidence from 
Malaysian public listed companies. International Business Research, 5(9), p120.

Sierra, G. E., Talmor, E., \& Wallace, J. S. (2006). An examination of multiple governance forces within bank holding companies. Journal of Financial Services Research, 29(2), 105-123.

Singh, A., \& Whittington, G. (1975). The size and growth of firms. The Review of Economic Studies, 42(1), 15-26.

Williamson, O. E. (1979). On the governance of the modern corporation. Hofstra L. Rev., 8, 63.

Yang, C.-H., \& Chen, K.-H. (2009). Are small firms less efficient? Small Business Economics, 32(4), 375-395.

Yermack, D. (1996). Higher market valuation of companies with a small board of directors. Journal of Financial Economics, 40(2), 185211. 